\title{
Attitudes of Finnish Students towards Immigrants
}

\section{ISMO SÖDERLING}

\section{Director}

The Population Research Institute

Väestöliitto, The Family Federation of Finland

Helsinki, Finland

\begin{abstract}
Traditionally Finland has been the losing party in migration. During the last hundred years about 600,000 Finns have emigrated permanently. Since the late 1980 s the migration balance has been positive to Finland due to decreased emigration and increased migration, especially from the former Soviet Union area. The aim of the paper was to give answers to the following questions: What are the attitudes towards immigrants and demographic internationalism among the students in Finland? What are the main factors explaining the differences? How do the students fit into Berry's acculturation model (his model consists of four acculturation groups: integrated, assimilated, segregated, and marginalized groups)?

The material was collected in May 1994. The population of the study consisted of all the students who started their studies between 1990-1993 at the University of Turku. The sample was 300 and 187 students returned the questionnaire $(62.3 \%)$.

Using factor analysis and sum-variables four different attitude groups were created: ethnocentrics $(35 \%)$, hesitants $(21 \%)$, egoists $(13 \%)$, and globalists $(31 \%)$. The results of the study indicated that Berry's model is also useful when categorizing the attitudes of the people of the host country: more than $92 \%$ of the globalists had an integrative opinion about immigration. As few as $4 \%$ of the globalists were marginalists (against immigration), while the corresponding figure among ethnocentrics was $14 \%$.
\end{abstract}

Keywords: immigration, attitude, accultaration, Finland

\section{Introduction}

Migration to Finland - including refugeeism and immigration - is a fairly new phenomenon in Finland. Traditionally, Finland has been the losing party in migration: during the last hundred years about 600,000 Finns have emigrated permanently (Korkiasaari and Söderling 1995). Since the late 1980s the migration balance has been positive to Finland due to decreased emigration and increased immigration from the former Soviet Union area. Also the number of refugees has increased. The total number of foreign citizens in Finland in January 1, 1995 was 62,000 (1.2\% of the total population). This proportion is probably the smallest one among the Western European countries - but the growth rate is the fastest. The number of refugees in Finland is 
12,000 (Söderling 1994, 142-144; Sosiaali- ja terveysministeriö/pakolaistoimisto 1995, 55).

Since Finland is at the beginning of the multiculturalism and integration process, interest in attitudes towards immigrants has been rather little even among researchers. Jaakkola has recently published (1995) a book on the increased tension among Finns in their attitudes to foreigners (Jaakkola 1995). Her study also makes a comparison between the Finnish and Swedish attitudes to immigrants. Some of the questions presented in her (Jaakkola 1995) and Westin's (1987) reports have been used in my pilot study.

The results of this paper are based on empirical material which was collected in Turku in May 1994. The target group of the pilot study was all the students studying at the University of Turku at that time. The students were chosen because they are the future intellectual and political leaders of the country. Being young adults it is presumably difficult to influence their opinions ("What the students are today, the whole society will be in the future").

The aim of this paper is to give answers to the following questions:

1. What are the attitudes towards immigration and demographic internationalism among the students in Finland (especially in Turku)?

2. What are the main factors explaining the differences?

3. How do the students fit into Berry's $(1990,1995)$ well known acculturation model? This model is based on two questions, which in this study were asked in the following way:

a) Do you think, it is important to create good relations with immigrant groups? Yes/No

b) Do you consider it is important that the immigrant groups can maintain their own cultural identity and character? Yes/No

The importance of maintaining cultural identity...

Relations with immigrant groups are important

Yes

\begin{tabular}{l|l|c|}
\cline { 2 - 3 } Yes & Integration & Assimilation \\
\cline { 2 - 3 } No & Segregation & Marginaliztion \\
\cline { 2 - 3 } & &
\end{tabular}

The attitudes were also studied by factor analysis and the results were compared between Berry's model and the model based on the factor analysis results.

4. What the students know about the magnitude and nature of immigration to Finland: the basic idea is to explain how well the students are informed on the phenomenon?

This a pilot study of a main study which starts in August 1995.

\section{Material}

The research material was collected in May 1994. The population of the study consisted of all the students who had started their studies between 1990-1993 and who even in 1994 studied at the University of Turku. All faculties were included in the study. The sample was 300 and the questionnaire (containing 134 variables altogether) 
was sent only once. 187 students returned the questionnaire $(62.3 \%)$. Because the study is a pilot one, loss analyses were not made. The loss was random studied by the faculties (see Table 1).

$\mathrm{T}$ a b l e 1 . All students and the students returning the questionnaire by faculty

$\begin{array}{lcr}\text { Faculty } & \begin{array}{c}\text { Students by faculty in spring 1994, } \\ \text { all students. }\end{array} & \begin{array}{r}\text { Students of this } \\ \text { by facul }\end{array} \\ \text { Social science } & 12 & 14 \\ \text { Law school } & 9 & 15 \\ \text { Science } & 22 & 23 \\ \text { Humanities } & 30 & 22 \\ \text { Medical school } & 13 & 7 \\ \text { Pedagogics } & 14 & 19 \\ \text { Total \% } & 100 & 100 \\ \text { N } & 12,725 & 187\end{array}$

Among the university students, the share of female students was $66.1 \%$ in $1994-$ this was also the distribution between the genders in the study (see: Turun Yliopisto, toimintakertomus 1994).

\section{Results}

The students were rather satisfied with the laws and regulations concerning immigration to Finland: one-fourth of the students considered the regulations too strict, and almost the same proportion were of the opposite opinion (23\% saw them as too liberal). According to faculty, some differences were found (Table 2).

$\mathrm{T}$ a b l e 2 . The opinion on the present regulations concerning immigration, by faculty, \%

$\begin{array}{lrrrrrrr} & \text { Soc. } & \text { Law } & \text { Science } & \text { Human. } & \text { Medical } & \text { Pedag. } & \text { Total } \\ \text { Strict } & 35 & 14 & 26 & 26 & 33 & 15 & 24 \\ \text { Liberal } & 27 & 32 & 29 & 7 & - & 29 & 22 \\ \text { Suitable } & 38 & 54 & 45 & 67 & 67 & 56 & 54 \\ \text { Total, \% } & 100 & 100 & 100 & 100 & 100 & 100 & 100 \\ \text { Total, N } & 26 & 28 & 42 & 43 & 12 & 34 & 187 \\ \text { Khi }=17.961 ; \mathrm{p}=0.05^{*} & & & & & & & \end{array}$

Students of the law school saw the present regulations as more liberal. The students of the pedagogical faculty had parallel opinions. This result is very interesting, since teachers and lawyers have an important role as formers of public opinion.

Of all the students, about one-third were ready to allow more refugees to move to Finland. In the study made by Jaakkola $(1995,10)$ the corresponding figure (among students) was also $33 \%$. The students at the medical school had the most liberal attitude - the law school students had also in this respect the most restrictive opinions.

Female students had a more positive attitude to immigration than men: only $17 \%$ of the women considered the Finnish immigration policy to be too liberal. The corresponding figure for men was $30 \%(\mathrm{khi}=7.95$; prob. $=0.02 *)$. 
Sixty-nine percent of the students had an integrative attitude to immigration - giving yes-answers to both questions by Berry. Only one out of ten students - fortunately sees no contacts with immigrants as important. The marginalists came from two faculties, especially from the law school and science. Studied by gender, the male students formed a clear majority among marginalists ( $61 \%$ were men). Correspondingly, the female students formed the majority in the integration category $(67 \%$, khi $=6.96$, $\mathrm{p}=0.07)$.

The importance of maintaining cultural identity

Relations with immigrant Yes

No groups are important

\begin{tabular}{c|c|c|}
\cline { 2 - 3 } Yes & Integration & Assimilation \\
& $69 \%$ & $12 \%$ \\
\cline { 2 - 3 } No & Segregation & Marginalization \\
\cline { 2 - 3 } & $9 \%$ & $10 \%$ \\
\hline
\end{tabular}

As expected, there was a close connection between Berry's acculturation categories and attitudes to immigration: one-third of integrative students considered the regulations too strict - in the marginalization group no subjects held this opinion (see Table 3)

T a b l e 3. The connection between Berry's acculturative categories and attitude to immigration, \%

$\begin{array}{lccccc}\text { Immigration } & \text { Integration } & \text { Assimilation } & \text { Segregation } & \text { Marginalizat. } & \text { Total } \\ \text { restrictions are } & 32 & 5 & 6 & - & 23 \\ \text { Strict } & 15 & 48 & 35 & 44 & 24 \\ \text { Liberal } & 53 & 47 & 59 & 56 & 53 \\ \text { Suitable } & 100 & 100 & 100 & 100 & 100 \\ \text { Total, \% } & 123 & 21 & 17 & 18 & 179 \\ \text { Total, N } & & & & \end{array}$

$\mathrm{Khi}=27.39, \mathrm{p}=0.0001 * * *$

Berry's classification was not related to municipality type (urban-rural dichotomy): of urban students, $69 \%$ were integrative, while the corresponding figure for rural students was $67 \%$. However, Berry's model was related more to the number of inhabitants ("size") of the home municipality: the majority of the marginalists were from municipalities with less than 10,000 inhabitants, while assimilated students were from big cities (Table 4):

Though the result is not significant, it gives some elements for further speculation/discussion. Students in the assimilation group were from big cities (on the Finnish scale): assimilation means that the members of the host society are not interested in cooperation with immigrants but allow them to maintain their own culture. This seems to be a case of the negation of the contact hypothesis: the more you meet the immigrants, the less it is needed to maintain the cultural identity.

Berry's categories were closely connected with the variables including, for example, human interest. Integrative students also took the most positive view towards homosexuality: more than $90 \%$ of them accepted homosexuality, while in the marginal group, the corresponding figure was only $27 \%\left(\mathrm{khi}=63.18, \mathrm{p}=0.000^{* * *}\right)$. 
$\mathrm{T}$ a b 1 e 4 . Berry's acculturate categories by size of the place of domicile, \%

$\begin{array}{lccccr} & \text { Integration } & \text { Assimilation } & \text { Separation } & \text { Marginaliz. } & \text { Total } \\ \text { Under } 10000 & 22 & 19 & 34 & 50 & 26 \\ 10,000-30,000 & 28 & 10 & 24 & 17 & 24 \\ 30,001-150,000 & 23 & 47 & 24 & 17 & 25 \\ \text { Over } 150,000 & 27 & 24 & 18 & 16 & 25 \\ \text { Total, } \% & 100 & 100 & 100 & 100 & 100 \\ \text { Total, N } & 100 & 100 & 100 & 100 & 100\end{array}$

$\mathrm{Khi}=14.93, \mathrm{p}=0.09$

The questionnaire included 28 propositions scaled from $1-5(1=$ fully agree, $5=$ fully disagree). The two-factor model gave the best results (in the following table the propositions have been presented in a shortened form):

T a b l e 5. Results of the two-factor model: the bold typed variables have loadings over .569.

1. Strong leaders are needed

4. Young people need stricter upbringing

11. There is not enough law and order

14. Modern society is too liberal

18. Because of the unemployment, immigration should be restricted.

23. If the unemployment increases, one part of the immigrants should be sent back

25. Foreigners are welcome to visit Finland

26. I would allow a foreigner to become a Finnish citizen

27. I would accept a foreigner as my next door neighbor

28. To marry a foreigner is acceptable

VP

Explanation level/lfactor

Explanation level, total

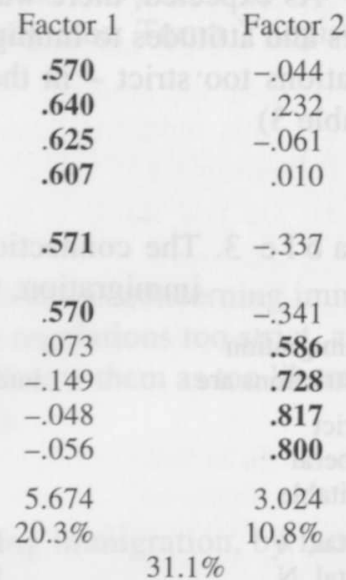

$31.1 \%$

The factors were given the following names:

Factor 1: The hostility - hospitality -factor

Factor 2: The localism - internationalism -factor

The sum-variable was calculated using the variables obtaining the highest loadings on both factors: the first sum-variable was calculated from six variables (see the output above), while the second sum-variable was based on four variables (variables 25-28). Both of the sum-variables consisted of two categories: by crosstabulating these two-category sum-variables, four different groups were created:

Hostile-minded

Local-minded

International-minded

\begin{tabular}{|c|c|}
\hline $\begin{array}{c}35 \% \\
\text { Ethnocentrics }\end{array}$ & $\begin{array}{c}21 \% \\
\text { Hesitants }\end{array}$ \\
\hline $13 \%$ & $31 \%$ \\
Egoists & Globalists \\
\hline
\end{tabular}


There was a close connection between the results obtained by Berry's classification and the factor analysis. More than $92 \%$ of the Globalists had an integrative opinion about immigration. On the other hand, only $49 \%$ of the Ethnocentrics had the same opinion. As few as $4 \%$ of the Globalists were Marginalists, while the corresponding figure among the Ethnocentrics was $14 \%$.

When studying the information level about movement to Finland, three questions was asked:

1. Which are the three biggest refugee groups in Finland? (Somalians, "Jugoslavians", Vietnamese)

2. What is the number of refugees in Finland? $(10,000)$

3. What is the number of immigrants (foreign citizens) in Finland? $(60,000)$

The most positive group towards immigration - integrative students - had the least information about the immigration situation in Finland. On the contrary, the students of the marginal and assimilation groups were best informed about the number of the refugees and immigrants in Finland. According to this, the positive attitude among the integration groups is perhaps more emotional than rational. This is worth further study in the future.

$\mathrm{T}$ a b l e 6 . Which are the three biggest refugee groups in Finland? (It is not necessary to mention them in order of magnitude), \%

$\begin{array}{lrrrrr}\text { Knows all 3 groups } & 18 & 21 & 18 & 28 & 19 \\ \text { Knows two groups } & 57 & 63 & 58 & 61 & 59 \\ \text { Knows one group } & 25 & 16 & 24 & 11 & 22 \\ \text { Total, \% } & 100 & 100 & 100 & 100 & 100 \\ \text { Total, N } & 120 & 19 & 17 & 18 & 174\end{array}$

Khi $=2.09, \mathrm{p}=0.83$

The result of the test is not significant due to the small number of cases in the assimilation and marginalization categories.

A mean analysis was also made. The results were similar to the information in Table 6.

$\mathrm{T}$ a b l e 7. The estimated number of refugees and immigrants in Finland in spring 1994 , mean analysis

$\begin{array}{lrcc} & \mathrm{N} & \text { Mean of immigrants } & \text { Mean of refugees } \\ \text { Integration } & 113 & 42939 & 16411 \\ \text { Assimilation } & 19 & 62894 & 15422 \\ \text { Segregation } & 16 & 34687 & 10525 \\ \text { Marginalization } & 18 & 47694 & 14833 \\ \text { Correct answers } & & 60000 & 10000 \\ \text { F-value } & & 0.272 & 0.778 \\ \text { d.f. } & & 3.169 & 3.167 . \\ \text { Prob. (F) } & & 0.845 & 0.51\end{array}$

In general the results (means) conform to each other, the F-test was not significant in either analysis. 


\section{Summary and conclusions}

Finland's migration balance is at present a positive one. However, the foreign minority is growing very fast, due to the eastern migration pressure. Only a few studies have been made in Finland on the attitudes of the Finns towards foreigners. More thorough research is needed to give guidelines on how to organize and develop the Finnish society in the future.

Berry's model is usually applied to study immigrant groups. The results of the present study indicate that Berry's model is also useful when categorizing the attitudes of the people of the host country.

Although the students on the whole had a very positive attitude towards immigrants, there were great differences between the faculties. The attitudes were not related to the municipality type (rural - urban dimension). The size of the home municipality explained a lot of the variance. However, the Integrative type was typical in all municipality sizes. The Marginalists came from small municipalities - the roots of the assimilated students were in big cities.

Four different kinds of attitude categories were found using the factor analysis. The biggest group was termed Ethnocentrics (35\%). These students appeared to be hostile-minded. At the same time, they were local minded - immigrants were not necessarily accepted into Finland with open arms.

A close connection between the attitude groups obtained with the factor analyses and Berry's classification was found.

Students belonging to the Assimilation or Marginalization groups had best information about the immigration situation in Finland. The following question should be asked: is the positive attitude presented by the integrative student connected with emotional rather than rational aspects?

\section{References}

Berry, J. W. 1990. Psychology of acculturation: understanding individuals moving between cultures. In: Applied Cross-Cultural Psychology, edited by R.W. Brislin. Newbury, CA: Sage Publications.

Berry, J. W. 1995. Multicultural and ethnic attitudes in Canada: contemporary views about the multiculturalism policy and ethno-cultural groups. In: Multiculturalism in the Nordic Societies: Proceedings of the 9th Nordic Seminar for Researchers on Migration and Ethnic Relations: final report, edited by Jan Hjarn $\emptyset$, pp. 51-58. TemaNord 1995:516. Copenhagen: Nordic Council of Ministers.

Jaakkola, Magdalena. 1995. Suomalaisten kiristyvät ulkomaalaisasenteet. Työpoliittinen tutkimus No. 101. Helsinki: Työministeriö.

Korkiasaari, Jouni and Ismo Söderling. 1994. Muuttoliike. In: Suomen väestö, edited by Seppo Koskinen et al., pp. 226-264. Helsinki: Gaudeamus.

Sosiaali- ja Terveysministeriö, Pakolaistoimisto. 1995. Tilastotietoa, Neljännesvuositilasto 4/1994. MoniTori (1):55.

Söderling, Ismo. 1994. Eurooppa liikkeellä 1990-luvulla. In: Eurooppalainen ihminen, edited by JuhaPekka Lehtonen and Leena Uusihakala, pp. 134-150. Helsinki: Historian ja yhteiskuntaopin opettajien liitto HYOL.

Turun Yliopisto. Toimintakertomus 1994.

Westin, Charles. 1987. Den toleranta opinionen: Inställningen till invandrare 1987. Rapport nr. 8 från DEIFO. Stockholm: Delegationen för Invandrarforskning. 